\title{
Ionic Mechanisms Involved in Muscarinic Regulation of Neuronal and Paraneuronal Activity ${ }^{\dagger}$
}

\author{
Akinori Akaike \\ 2nd Department of Pharmacology, Faculty of Pharmacy and Pharmaceutical Sciences, \\ Fukuyama University, Fukuyama 729-02, Japan
}

Received August 22, 1991 Accepted November 14, 1991

\begin{abstract}
The characteristics of neuronal and paraneuronal muscarinic inhibition and excitation were analyzed using rat caudate nucleus (CN) slices and isolated chromaffin cells obtained from the rat adrenal medulla. In $\mathrm{CN}$ neurons, either acetylcholine (ACh), carbachol, or muscarine inhibited orthodromically activated firing, while nicotine had no effect on neuronal activity. Muscarine decreased the amplitude of EPSPs without altering the resting membrane potential (RMP), input impedance and EPSP time courses. These results indicate that muscarinic receptors produce the presynaptic inhibition of synaptic transmission in the $\mathrm{CN}$. In adrenal chromaffin cells, it was found that $\mathrm{ACh}$, muscarine, and nicotine all increased extracellularly recorded firing. During voltage clamp recording at the RMP, $\mathrm{ACh}$ induced a transient inward current (fast response) followed by a long-lasting current (slow response). Muscarine induced the slow response, whereas nicotine induced the fast response. Muscarine reduced the inward $\mathrm{K}^{+}$current produced by the application of a high $\mathrm{K}^{+}$medium to cells. During patch clamp recording, muscarine decreased the opening rate of the single $\mathrm{K}^{+}$channels. These results indicate that the muscarinic excitation of adrenal chromaffin cells was triggered by a reduction in the number of active $\mathrm{K}^{+}$channels at the RMP.
\end{abstract}

A great variety of neurons and paraneurons show responses to acetylcholine $(\mathrm{ACh})$ which are mediated by muscarinic receptors. In most of these cells, muscarinic receptor stimulation causes a change in membrane conductance by opening or closing selective channels, and the existence of several ion channels linked to

†This work was presented at the 64th Annual Meeting of the Japanese Phamacological Society, March 1991 when the author received the Award for Encouragement of Young Investigators from the Japanese Pharmacological Society. these receptors results in a diversity of responses. For example, muscarinic excitation is seen throughout the central nervous system (CNS), the autonomic ganglia, and the adrenal medulla (1), while muscarinic inhibition is also seen in a broad area of the CNS, including the cerebral cortex, the caudate nucleus (CN), and the thalamus.

In the CNS, the highest concentrations of cholineacetyltransferase, acetylcholinesterase, and $\mathrm{ACh}$ itself are found in the $\mathrm{CN}$ and the putamen $(2,3)$. Subcellular fractionation studies show that most of the cholineacetyltrans- 
ferase activity is concentrated in nerve endings. In addition, histological and biochemical studies have demonstrated the presence of dense muscarinic binding sites in the $\mathrm{CN}(4$, 5). Thesc findings indicate that the muscarinergic cholinergic system plays an important role in the regulation of $\mathrm{CN}$ neuronal activity. Since both muscarinic antagonists and dopaminergic agonists are effective in relieving the symptoms of Parkinson's disease, the muscarinic cholinergic system and the dopaminergic system are considered to have opposing effects on $\mathrm{CN}$ neurons $(6,7)$.

With regard to the peripheral nervous systcm, there are a number of studies concerning the effects of muscarinic excitation on the autonomic ganglia $(8,9)$ and the adrenal medulla (10), and these studies have shown that muscarinic receptor-mediated excitation is linked to $\mathrm{K}^{+}$channels. Recent studies have also shown that the chromaffin cells of the adrenal medulla provide an excellent model of the nervous system (11), since the adrenal chromaffin cells possess characteristics similar to those of autonomic ganglion cells. Moreover, the chromaffin cells are suitable for patch clamp experiments, since isolated cells with homogeneous properties are easily obtained (12).

In this review, I would like to elucidate the mechanisms underlying muscarinic receptormediated inhibition of caudate nucleus neurons and excitation of adrenal chromaffin cells.

\section{Muscarinic inhibition of caudate nucleus neurons}

ACh-containing $\mathrm{CN}$ neurons are considered to make a local circuit because lesions of brain regions sending fibers to the $\mathrm{CN}$ do not reduce the $\mathrm{ACh}$ content of this nucleus $(13,14)$. The neuronal mechanisms of the cholinergic system in the $\mathrm{CN}$ have been investigated by determining the effects of cholinergic agonists on $\mathrm{CN}$ neuronal activity. Early iontophoretic studies demonstrated that $\mathrm{ACh}$ has both excitatory and inhibitory effects on $\mathrm{CN}$ neurons $(15-17)$. In vitro studies using slice prepara- tions of the CN have shown two kinds of cholinergic actions: 1) inhibition mediated by muscarinic receptors $(18,19)$ and 2) excitation mediated by both nicotinic and muscarinic receptors $(19,20)$. However, these studies did not assess whether inhibition or excitation was dominant in the $\mathrm{CN}$.

Therefore, we quantitatively analyzed the effects of cholinergic agents on $\mathrm{CN}$ neurons to determine the dominant effect of cholinergic systems on neuronal transmission in this nucleus (21).

$\mathrm{CN}$ slices $(300 \mu \mathrm{m})$ were prepared from decapitated male Wistar rats using a Vibratome. Slices containing the rostral part of the $\mathrm{CN}$ were submerged completely in the recording chamber, which was continuously perfused with artificial cerebrospinal fluid at $33-34^{\circ} \mathrm{C}$. Extracellular and intracellular recordings were made from $\mathrm{CN}$ neurons using glass microelectrodes filled with $2 \mathrm{M} \mathrm{NaCl}$ and $3 \mathrm{M} \mathrm{KCl}$, respectively. A bipolar stimulating electrode was placed on the surface of the slice to produce orthodromic responses. Drugs were added to the bath by switching the perfusion system.

The effect of carbachol on spikes induced by submaximal and supramaximal stimulation was examined. If excitation rather than the inhibition was the predominant effect of cholinergic agents, the number of spikes clicited by submaximal stimulation should increase, while the number of spikes should decrease if the inhibition was dominant. Carbachol $\left(10^{-7}\right.$ to $10^{-5} \mathrm{M}$ ) dose-dependently reduced the number of spikes produced by both submaximal and supramaximal stimulation, suggesting that the inhibition is the dominant action of cholinergic agents in the $\mathrm{CN}$.

Carbachol $\left(10^{-7}-10^{-5} \mathrm{M}\right)$ and muscarine $\left(10^{-7}-10^{-5} \mathrm{M}\right)$ dose-dependently inhibited spike generation by local stimulation in $\mathrm{CN}$ neurons with an $\mathrm{ED}_{50}$ of $7.0 \times 10^{-7}$ and 8.9 $\times 10^{-7} \mathrm{M}$, respectively. In contrast, nicotine had no effect at concentrations of $10^{-7}$ to $10^{-3} \mathrm{M}$. ACh alone at concentrations up to $10^{-4} \mathrm{M}$ also had no effect, although higher concentrations $\left(10^{-3}\right.$ to $\left.10^{-2} \mathrm{M}\right)$ inhibited spike generation with an $\mathrm{ED}_{50}$ of $1.6 \times 10^{-3}$ 
M. However, the acetylcholinesterase inhibitor physostigmine $\left(10^{-6} \mathrm{M}\right)$ shifted the dose-response curve for ACh-induced inhibition to the left, yielding an $\mathrm{ED}_{50}$ of $4.1 \times 10^{-6} \mathrm{M}$. Atropine at concentrations of $3 \times 10^{-8} \mathrm{M}$ to $10^{-6} \mathrm{M}$ dose-dependently reduced the inhibitory effects of carbachol. The Schild plot (22) for the antagonism of carbachol-induced inhibition by atropine yielded a mean $\mathrm{pA}_{2}$ value of 7.6, indicating that the $K_{d}$ value of atropine for muscarinic receptors was in the order of $10^{-8} \mathrm{M}$. This value was similar to that obtained by receptor-binding assays using atropine as a ligand, which have demonstrated that the $K_{d}$ of atropine for brain muscarinic receptors was between $10^{-9}$ and $10^{8} \mathrm{M}(23$, 24).

The mechanisms underlying the muscarinic inhibition of $\mathrm{CN}$ neurons were analyzed using intracellular recording. Carbachol did not alter the resting membrane potential (RMP) or input impedance, although it markedly inhibited excitatory postsynaptic poientials (EPSPs) and action potentials (Fig. 1A). Muscarine also
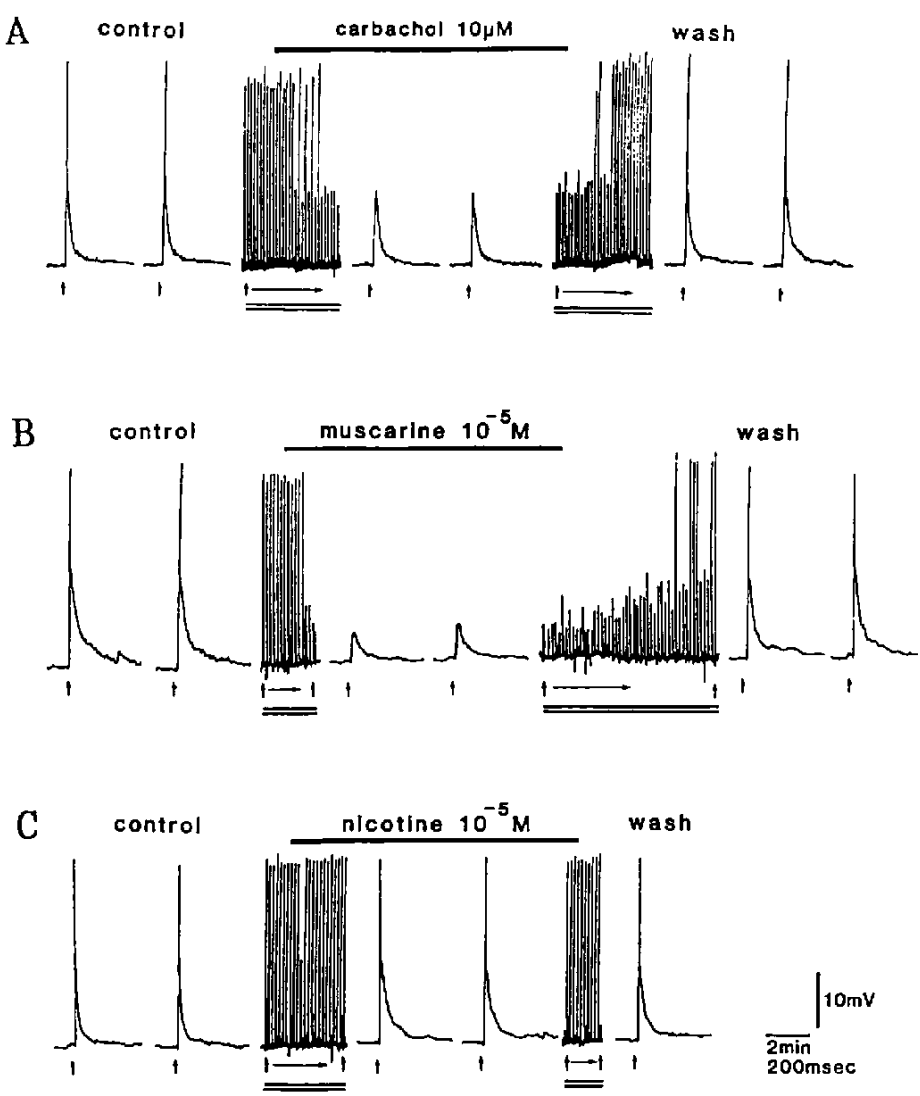

Fig. 1. Effects of carbachol $\left(10^{-5} \mathrm{M}, \mathrm{A}\right)$, muscarine $\left(10^{-5} \mathrm{M}, \mathrm{B}\right)$, and nicotine $\left(10^{-5} \mathrm{M}, \mathrm{C}\right)$ on the intracellular records of $\mathrm{CN}$ neurons. Traces A-C show pen-recorder charts. Note that the amplitudes of the action potentials have been attenuated by the limited high-frequency range of the recorder. Single bars above the traces indicate the duration of drug application. Double bars under the traces indicate records made at a slow paper-speed (calibrations $=2 \mathrm{~min}$ ) in order to demonstrate the time course of the drug effects. Other traces were drawn at a higher paper speed with calibrations of $200 \mathrm{msec}$. Arrows under the traces indicate local stimulation to elicit an orthodromic response. From Akaike et al. (21), with permission from J. Pharmacol. Exp. Ther. 
showed an inhibitory effect in a manner similar to carbachol (Fig. 1B). In contrast, nicotine had no effect on the RMP, input impedance, or EPSPs induced by local stimulation (Fig. 1C). Carbachol reduced the peak amplitude of the EPSPs induced by the local stimulation, but did not alter the tau value of the rise or decay phase of the EPSP (Fig. 2). These results indicate that conductance at the synaptic area of the distal dendrites was not altered by carbachol (25). Evidence obtained from the intracellular study suggested that the inhibitory effects of $\mathrm{ACh}$ and muscarine were not derived from postsynaptic inhibition but rather from presynaptic inhibition. These findings were in agreement with those from a receptor-binding study showing that muscarinic receptors were located on presynaptic terminals in the CN (26).

This study also showed that carbachol produced a moderate postsynaptic excitation together with the potent presysnaptic inhibition mentioned above. Carbachol increased the number of action potentials elicited by a
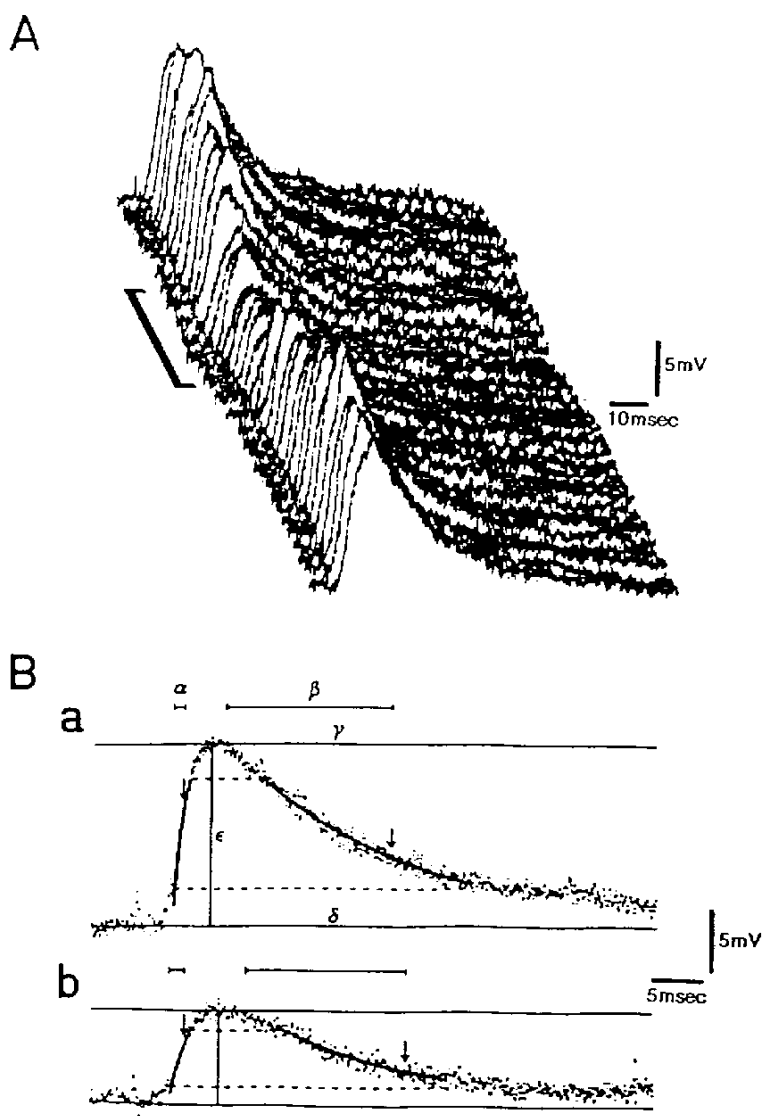

Fig, 2. Analysis of EPSPs evoked by the local stimulation of CN slices. A: Computer graphic presentation of a bird's-eye view of the EPSPs. The experiment started at the top trace and EPSPs were elicited at 10$\mathrm{sec}$ intervals. The bar at the left side of the traces show the duration of application of carbachol $\left(10{ }^{5} \mathrm{M}\right)$. B: Examples of computer analysis of EPSPs recorded (a) before and (b) during the application of carbachol (10 ${ }^{5}$ M). $\alpha$, tau of the rising phase. $\beta$, tau of the decay phase. $\gamma$ (or $\varepsilon$ ), EPSP amplitude. $\delta$, RMP. Figs. in panel $\mathrm{B}$ from Akaike et al. (21), with permission from J. Pharmacol. Exp. Ther. 
depolarizing pulse without affecting RMP or input impedance. These results are in line with those by Dodt and Misgeld (19) that carbachol produced slow excitation in $\mathrm{CN}$ neurons. However, further research to determine the ionic mechanisms underlying muscarinic excitation was difficult since cholinergic synapses were considered to be located at dendritic areas (21). Moreover, $\mathrm{CN}$ neurons were not suitable preparations for voltage and patch clamp studies. Therefore, we used adrenal chromaffin cells as a neuronal model to investigate mechanisms of muscarinic excitation.

\section{Muscarinic excitation of adrenal chromaffin cells}

Early studies on adrenal chromaffin cells of the rat (27) and guinea pig (28) have shown that both nicotinic and muscarinic receptors mediate ACh-stimulated catecholamine secretion. Douglas et al. (29) investigated gerbil chromaffin cells and found that ACh-induced depolarization was partially antagonized by hexamethonium, while it was completely blocked by hexamethonium in combination with atropine. These findings suggested the possible involvement of muscarinic receptors in the cholinergic excitation of rodent adrenal chromaffin cells. Therefore, we performed a patch clamp study to analyze the muscarinic and nicotinic mechanisms involved in $\mathrm{ACh}$ induced excitation of chromaffin cells freshly isolated from the rat adrenal medulla $(30,31)$.

Adrenal glands were removed from male Wistar rats under pentobarbital anesthesia, medullae were dissected out, and then incubated in a low $\mathrm{Ca}^{2+}$ medium containing $0.3 \%$ collagenase, $0.1 \%$ hyaluronidase, and $0.1 \%$ trypsin to obtain isolated chromaffin cells. Patch clamp recording was performed by the method of Hammil et al. (32). For the rapid application of test drugs, solutions were directly perfused onto the cells using a microinflow system (30). Single channel currents were automatically analyzed with programs written in C language and run on a UNIX operating system (31). Portions of the programs were based on the work of Sachs et al. (33) and
Akaike et al. (34).

Current clamp measurements of the membrane potential showed that $\mathrm{ACh}\left(10^{6}-10^{-4}\right.$ $\mathrm{M})$ depolarized cells in a dose-dependent manner (Fig. 3A). A low concentration $\left(10^{-6} \mathrm{M}\right)$ of $\mathrm{ACh}$ produced monophasic depolarization with a rapid rising phase and a slow decay phase. However, when the concentration of ACh was raised to $10{ }^{5} \mathrm{M}$, the depolarization apparently consisted of two components, i.e., rapid depolarization occurring immediately after the start of drug application and slow depolarization that developed after the cessation of superfusion. The slow component of depolarization became prominent with higher concentrations $\left(10^{4} \mathrm{M}\right)$ of ACh. Because most of the cells had an RMP value of -60 $\mathrm{mV}$, ACh-induced currents were recorded under voltage clamp conditions with a holding potential of $-60 \mathrm{mV}$ (Fig. 3B). ACh at concentrations of $10^{-5}$ to $10^{-4} \mathrm{M}$ produced two different sequential inward currents, a transient inward current with a rapid rising phase (the fast current response) and a persistent inward current with a slow rising phase (the slow current response). The ACh-induced fast response was accompanied by an apparent increase in membrane conductance, since there was an increase in the current induced by the application of hyperpolarizing pulses (Fig. $3 \mathrm{C}$ ). In contrast, the subsequent slow response was accompanied by a decrease in membrane conductance. These results suggest the involvement of different ionic mechanisms in the ACh-induced fast and slow responses.

To determine the receptors mediating these ACh-induced responses, the effects of $\mathrm{ACh}$, nicotine, and muscarine were compared by voltage clamp recording. As shown in Fig. 4A, both the fast and slow components of the ACh-induced current were dependent on the holding potential. The fast response was larger at $-80 \mathrm{mV}$ than at $-40 \mathrm{mV}$. Such voltage-dependent changes in the $\mathrm{ACh}$-induced fast current response were similar to those for the nicotine-induced current shown in Fig. 4B. In contrast to the fast response, the slow component of the ACh-induced current was smaller 
A

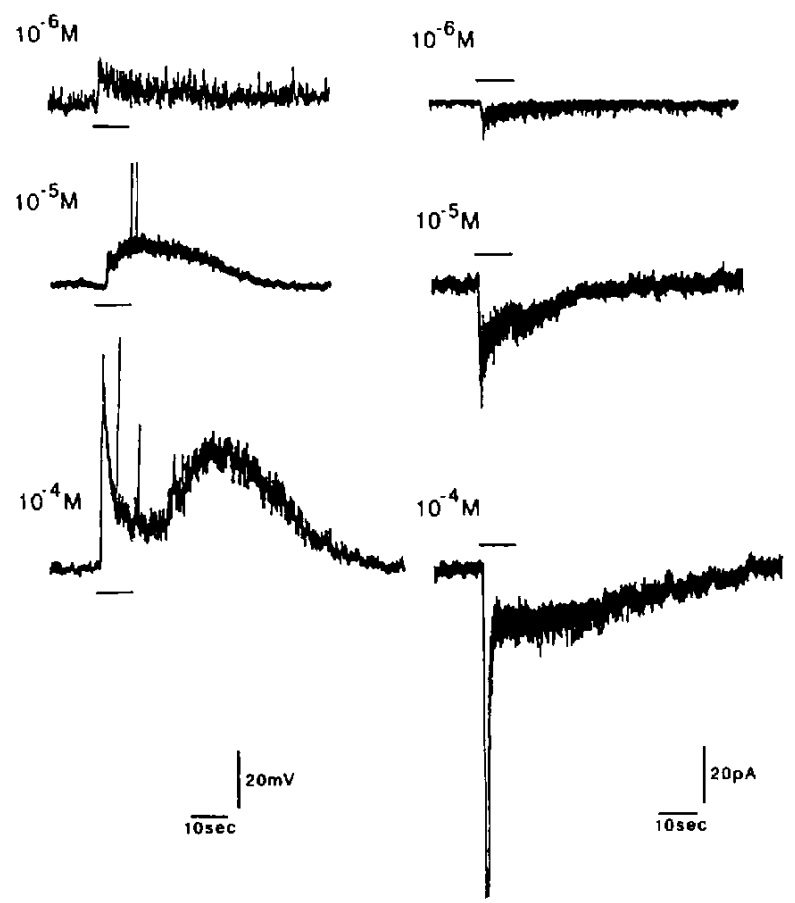

C
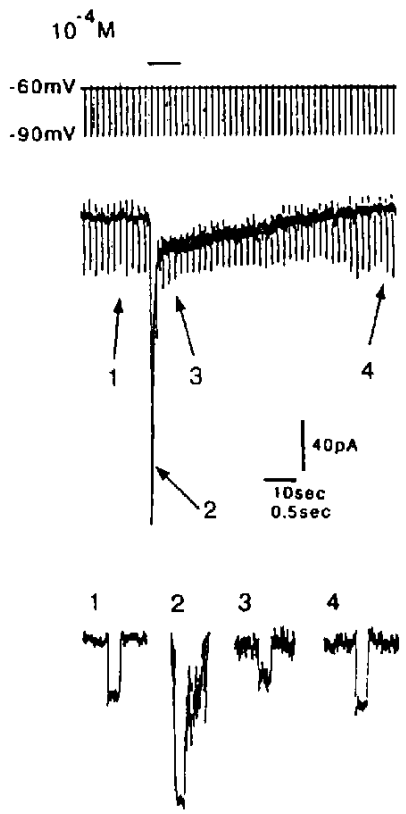

Fig. 3. ACh-induced depolarization and inward current shown by whole cell recordings. Bars under or above the traces show the duration of ACh application. A: RMP changes recorded under current clamp conditions. B: Drug-induced inward currents when the RMP was clamped at $-60 \mathrm{mV}$. The peak of the fast inward current at the bottom trace was cut $70 \%$ from the baseline. $\mathrm{C}$ : Conductance changes measured by switching the holding potential from $-60 \mathrm{mV}$ to $-90 \mathrm{mV}$ during voltage clamp recording. The top and second traces show the holding potential and whole cell current, respectively. The bottom traces represent the current evoked by a jump in holding potential under control conditions (1), during the ACh-induced fast response (2), during the slow response (3), and during recovery (4). Numbers $1-4$ in the bottom traces correspond to the same numbers in the middle trace. From Akaike et al. (30), with permission from $\mathrm{J}$. Pharmacol. Exp. Ther.

at $-80 \mathrm{mV}$ than $-40 \mathrm{mV}$. These changes resembled the voltage-dependent changes of the muscarine-induced current shown in Fig. 4C. Our results thus suggested that the fast and slow components of the ACh-induced current were mediated by nicotinic and muscarinic receptors, respectively.

The involvement of resting $\mathrm{K}^{+}$conductance in the muscarinic excitation of the chromaffin cells was suggested by the following evidence: 1) membrane conductance decreased as the slow $\mathrm{ACh}$ response increased, 2) the slow ACh or muscarine response decreased with hyperpolarization, and 3) the muscarine-in- duced current was recorded at $-60 \mathrm{mV}$ (voltage where most of the voltage-gated cation channels, including the voltage-dependent and $\mathrm{Ca}^{2+}$-dependent $\mathrm{K}^{+}$channels, are not activated $[35,36])$. The latter two findings indicate that the slow response was mediated by $\mathrm{K}^{+}$channels, which have a reversal potential more negative than the RMP, and not by $\mathrm{Na}^{+}$ or $\mathrm{Ca}^{2+}$, which have reversal potentials more positive than $0 \mathrm{mV}$. If muscarinic excitation was caused by the suppression of resting $\mathrm{K}^{+}$ channels, the inward $\mathrm{K}^{+}$current at the RMP should be decreased by muscarine.

To test this hypothesis, we examined the 


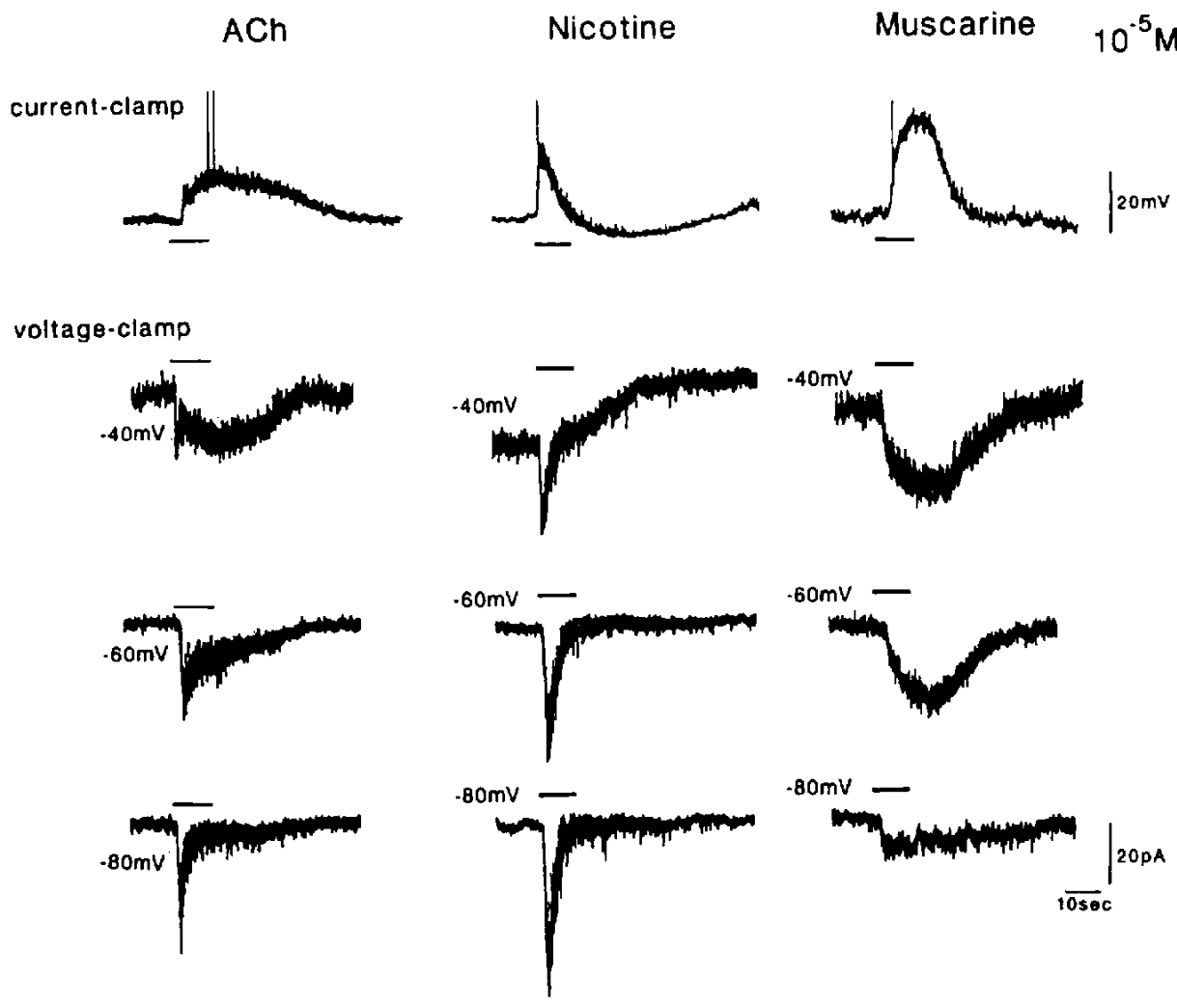

Fig. 4. Effects of $\mathrm{ACh}$, muscarine, and nicotine (all at $10^{-5} \mathrm{M}$ ) on the RMP during current clamp recording (top traces) and on whole cell current during voltage clamp recording (lower traces). Bars under the traces indicate the times of drug application. Traces are from Akaike et al. (30), with permission from $\mathrm{J}$. Pharmacol. Exp. Ther.

effects of muscarine on the inward current induced by increasing the external $\mathrm{K}^{+}$concentration (Fig. 5). When a medium containing $125 \mathrm{mM} \mathrm{K}^{+}$was applied, cells were depolarized to around $0 \mathrm{mV}$ during current clamp recording, and a large inward current was recorded at a potential more negative than -60 $\mathrm{mV}$. When the perfusion medium contained tetrodotoxin $\left(3 \times 10^{-7} \mathrm{M}\right)$ plus $\mathrm{CoCl}_{2}(5 \times$ $\left.10^{3} \mathrm{M}\right)$, inward current was still induced by perfusing cells with a high $\mathrm{K}^{+}$medium. These results indicate that a major component of the high $\mathrm{K}^{+}$-induced current seen at the RMP was an inward $\mathrm{K}^{+}$current flowing through $\mathrm{K}^{+}$ channels that were activated at potentials near the RMP, i.e., resting $\mathrm{K}^{+}$conductance or inward-rectifying $\mathrm{K}^{+}$channels (37).
Figure $5 \mathrm{~B}$ shows the effects of muscarine on the inward current induced by a high $\mathrm{K}^{+}$ medium. The membrane potential was clamped at $-60 \mathrm{mV}$, since most of the voltage-gated cation channels were not activated at this potential $(35,36)$. Muscarine $\left(10^{5} \mathrm{M}\right)$ induced a slow inward current and reduced the inward current produced by the high $\mathrm{K}^{+}$medium. Shifting of the baseline and suppression of the inward $\mathrm{K}^{+}$current occurred simultaneously, indicating that the production of an inward current by muscarine was accompanied by the suppression of resting $\mathrm{K}^{+}$ conductance. In other words, muscarinic receptor stimulation resulted in a reduction of the number of activated $\mathrm{K}^{+}$channels maintaining the RMP. 
A
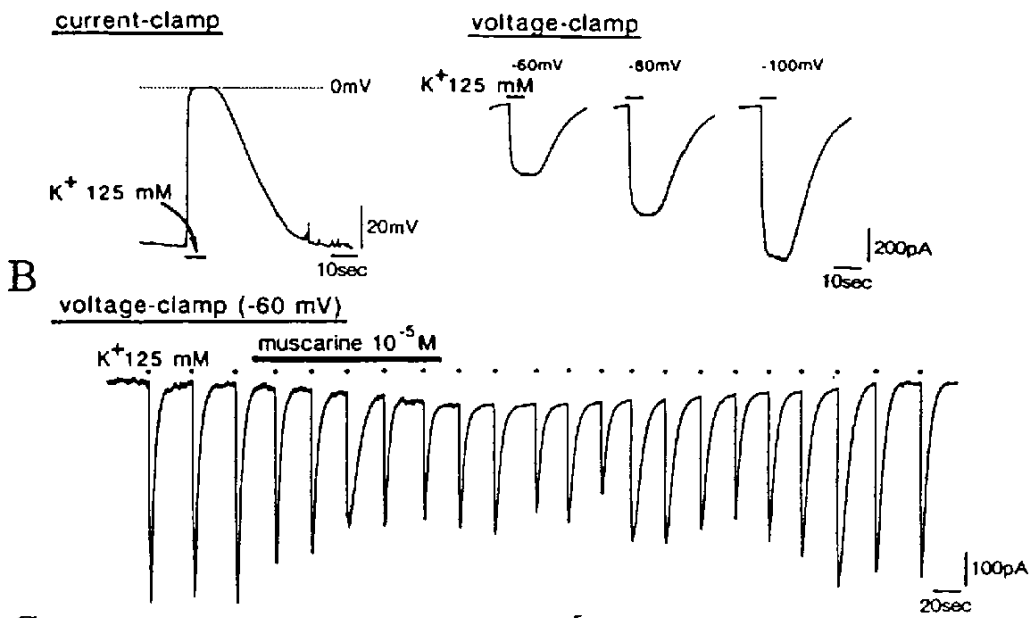

C
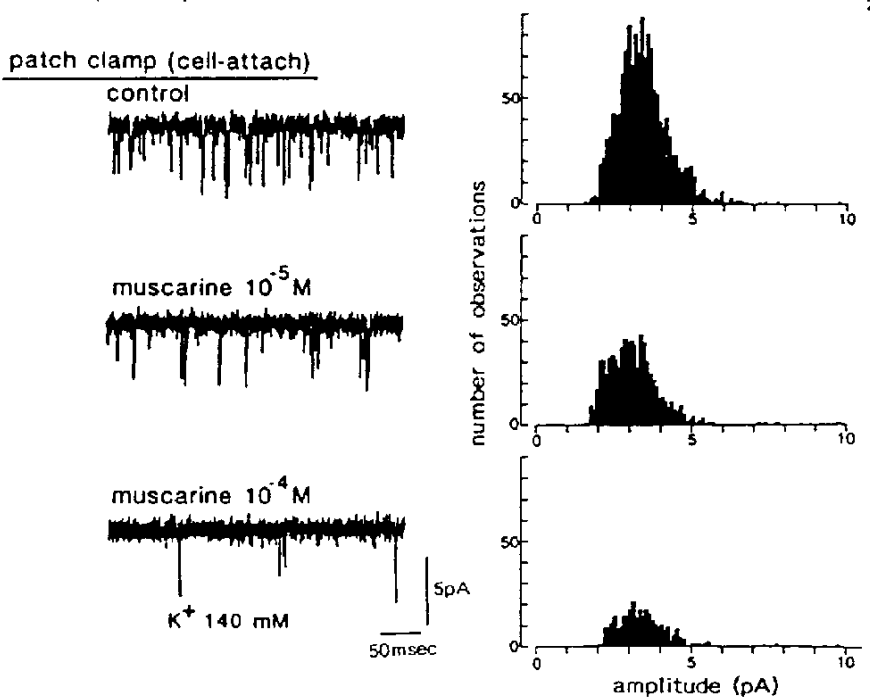

Fig. 5. Effect of muscarine on the inward $\mathrm{K}^{+}$current induced by the application of a high $\mathrm{K}^{+}(125 \mathrm{mM})$ medium to the cell. A: Depolarization and inward current induced by the high $\mathrm{K}^{+}$medium. Bars under the traces indicate the times of application of the high $\mathrm{K}^{+}$medium. B: Muscarine-induced reduction of the inward $\mathrm{K}^{+}$current during voltage clamp recording at $-60 \mathrm{mV}$. Solid circles and the bar above the trace show the times of high $\mathrm{K}^{+}$and muscarinc application, respectively. $\mathrm{C}$ : Effect of muscarine on high $\mathrm{K}^{+}$-induced currents in cell-attached patch recording. The records were obtained from the same cell with thrce different pipettes. The pipette solutions contained $\mathrm{K}^{+}$and muscarine $\left(10^{-5}\right.$ or $\left.10^{-4} \mathrm{M}\right)$. Muscarine was applied to the cell membrane by making a seal with the pipette containing the drug. The traces on the left show pen recordings of the single-channel currents, and the graphs on the right show histograms of the amplitude of single-channel currents continuously sampled for $21 \mathrm{sec}$. From Akaike et al. (30 and 31), with permission from J. Pharmacol. Exp. Ther.

Muscarinic inhibition of resting $\mathrm{K}^{+}$conductance has been reported in ileal myenteric neurons (38) and sympathetic ganglion cells
(39). Because the RMP (approximately -60 $\mathrm{mV}$ ) of adrenal chromaffin cells is more positive than the $\mathrm{K}^{+}$reversal potential (which is 
below $-80 \mathrm{mV}$, ref. 36 ), the $\mathrm{K}^{+}$current spontaneously flows from the inside to the outside of a membrane clamped at a potential near the RMP. The spontaneous outward $\mathrm{K}^{\dagger}$ current at the RMP is reduced if muscarine suppresses the $\mathrm{K}^{+}$channels that are active in the resting cell. Therefore, it seems plausible that the apparent inward current produced by muscarine was actually caused by a decrease in the spontaneous outward $\mathrm{K}^{+}$current.

To determine the properties of channels related to the inward $\mathrm{K}^{+}$current observed in whole cell recordings, single-channel currents were recorded at the RMP in the presence of a high $\mathrm{K}^{+}$medium. Single inward currents of cells in a high $\mathrm{K}^{+}$medium were recorded using the method for recording resting or AChactivated $\mathrm{K}^{+}$channels $(40,41)$ and an inward rectifier (42). Spontaneous inward currents with a brief open time were recorded at membrane potentials near the RMP when the $\mathrm{K}^{+}$ concentration of the medium was raised to more than $70 \mathrm{mM}$. Single-channel currents recorded with external $\mathrm{K}^{+}$concentration of 70 and $140 \mathrm{mM}$ showed a linear relationship between membrane potential and amplitude. The single-channel conductance of the current was estimated to be $37 \mathrm{pS}$ from the $\mathrm{I}-\mathrm{V}$ curve when the external $\mathrm{K}^{+}$was $140 \mathrm{mM}$. This value was similar to the single channel conductance of the resting $\mathrm{K}^{+}$channel $(39 \mathrm{pS})$ of atrioventricular nodal cells (40). The I-V curve of the current shifted to the right (towards positive potentials) as the $\mathrm{K}^{+}$concentration in the medium was increased. This high $\mathrm{K}^{+}$-induced current was blocked by tetraethylammonium (TEA) but not by tetrodotoxin or $\mathrm{Co}^{2+}$. Moreover, the high $\mathrm{K}^{+}$-induced current recorded in outside-out recording showed strong inward rectification. These results indicate that the currents induced in adrenal chromaffin cells by high external $\mathrm{K}^{+}$levels are mediated by $\mathrm{K}^{+}$channels that are active at potentials around the RMP and share common properties with the resting $\mathrm{K}^{+}$channels of heart cells.

Figure $5 \mathrm{C}$ shows the effects of muscarine on single-channel currents induced by a high ex- ternal $\mathrm{K}^{+}$concentration and recorded in the cell-attached configuration. Application of muscarine at $10^{-5}$ to $10^{-4} \mathrm{M}$ suppressed the number of channel events without affecting the current amplitude. The opening and closing times were not affected by muscarine, although the number of channel opening events induced by high $\mathrm{K}^{+}$was reduced by muscarine $\left(10^{-5} \mathrm{M}\right)$ to approximately $51 \%$ of the control level. This value was comparable to the results obtained by the whole cell clamp recording, in which the net $\mathrm{K}^{+}$current was reduced by muscarine $\left(10^{-5} \mathrm{M}\right)$ to $58 \%$ of the control value. Therefore, it is concluded that the activation of muscarinic receptors inhibited the opening of the $\mathrm{K}^{+}$channels that mediate the brief inward $\mathrm{K}^{+}$current in the presence of a high external $\mathrm{K}^{+}$concentration.

The activation of muscarinic receptors of atrioventricular nodal cells results in the activation of resting $\mathrm{K}^{+}$channels and produces hyperpolarization which decreases cellular activity (40). In contrast, activation of the muscarinic receptors of rat adrenal chromaffin cells resulted in the reduction of resting $\mathrm{K}^{+}$ channels with properties similar to those of nodal cells and produced depolarization which increased cellular activity. Thus, it is possible that the muscarinic response of adrenal chromaffin cells is mediated by a second messenger system that differs from that mediating the muscarinic response of heart cells $(41,43,44)$.

\section{Acknowledgments}

I would like to thank Dr. Shuji Takaori (Shimane Medical University) and Dr. Masashi Sasa (Dcpartment of Pharmacology, Faculty of Medicine, Kyoto University) for their generous advise and support during these studies.

\section{REFERENCES}

1 Kelly, J.S. and Rogawski, M.A.: Acetylcholine. In Neurotransmitter Actions in the Vertebrate Neryous System, Edited by Rogawski, M.A. and Barker, J.L., p. 143-183, Plenum Press, New York (1985)

2 Armstrong, D.M., Saper, C.B., Levey, A.I., Wainer, H.H. and Terry, R.D.: Distribution of cholinergic neurons in rat brain: Demonstrated by 
the immunocytochemical localization of choline acetyltransferase. J. Comp. Neurol. 216, 53-68 (1983)

3 Paxinos, G. and Butcher, L.L.: Organizational principles of the brain as revealed by choline acetyltransferase and acetylcholinesterase distribution and projections. In The Rat Nervous System I, Edited by Paxinos, G., p. 487-513, Academic Press, Sydney (1982)

4 Kobayashi, R.M., Palkovits, M., Hruska, R.E., Rothschild, R. and Yamamura, H.l.: Regional distribution of muscarinic cholinergic receptors in rat brain. Brain Res. 154, $13-23$ (1978)

5 Kuhar, M.J. and Yamamura, H.L.: Localization of cholinergic muscaninic receptors in rat brain by light microscopic radioautography. Brain Res, 110. $229-243$ (1976)

6 Clough, C.G., Bergmann, K.J. and Yahr, C.G. Cholinergic and dopaminergic mechanisms in Parkinson's disease after long-term L-dopa administration. Adv. Neurol. 40, 131-140 (1984)

7 Penney, J.B., Jr. and Young, A.B.: Speculations on the functional anatomy of basal ganglia disorders. Annu. Rev. Neurosci. 6, 73-94 (1983)

8 Brown, D.A., Gahwiler, B.H., Marsh, S.J. and Selyanko, A.A.: Mechanisms of muscarinic excitatory synaptic transmission in ganglia and brain. Trends Pharmacol. Sci. Supp. Subtypes of muscarinic receptors II, 66-71 (1986)

9 Lees, G.M. and Nishi, S.: Analysis of the mechanism of action of some ganglion-blocking drugs in the rabbit superior cervical ganglion. Br. J. Pharmacol. 46, 78-88 (1972)

10 Livett, B.G.: Adrenal chlomaffin cells in vivo. Physiol. Rev. 64, $1103-1161$ (1984)

11 Ozawa, S. and Sand, O.: Electrophysiology of excitable endocrine cells. Physiol. Rev. 66, 887-952 (1986)

12 Fenwick, E.M., Marty, A. and Neher, E.: A patch-clamp study of bovine chromaffin cells and of their sensitivity to acetylcholine. J. Physiol. (Lond.) 331, $577-597$ (1982)

13 McGeer, P.L., McGeer, E.G., Fibiger, H.C. and Wickson, V.: Neostriatal choline acetylase and cholinesterase following selective brain lesions. Brain Res. 35, 308-314 (1971)

14 Butcher, S.G. and Butcher, L.L.: Origin and modulation of acetylcholine activity in the neostriatum. Brain Res. 71, 167-171 (1974)

15 Bloom, F.E., Costa, E. and Salmoiraghi, G.C.: Anesthesia and the responsiveness of individual neurons of the caudate nucleus of the cat to acetylcholine, norepinephrine and dopamine administered by microiontophoresis. J. Pharmacol. Exp.
Ther. 150, $244-252$ (1965)

16 Spehlmann, R.: The effects of acetylcholine and dopamine on the caudate nucleus depleted of biogenic amines. Brain Res. 98, 219-230 (1975)

17 Bernardi, G., Floris, V., Marciani, M.G., Morocutti, C. and Stanzione, P.: The action of acetylcholine and L-glutamic acid on rat caudate neurons. Brain Res. 114, 134 - 138 (1976)

18 Takagi, M. and Yamamoto, C.: Suppressing action of cholinergic agents on synaptic transmission in the corpus striatum of rats. Exp. Neurol. 62, 433 443 (1978)

19 Dodt, H.U. and Misgeld, U.: Muscarinic slow excitation and muscarinic slow inhibition of synaptic transmission in the rat neostriatum. J. Physiol. (Lond.) 380, 593-608 (1986)

20 Misgeld, U., Weilerm, M.H. and Bak, I.J.: Intrinsic cholinergic excitation in the rat neostriatum: Nicotinic and muscarinic receptors. Exp. Brain Res. 39, $401-409$ (1980)

21 Akaike, A., Sasa, M. and Takaori, S.: Muscarinic inhibition as a dominant role in cholinergic regulation of transmission in the caudate nucleus. J. Pharmacol. Exp. Ther. 246, 1129-1136 (1988)

22 Arunlakshana, O. and Schild, O.: Some quantitative uses of drug antagonists. Br. J. Pharmacol. 14, $48-58$ (1959)

23 Yamamurd, H.I. and Snyder, S.: Muscarinic cholinergic binding in rat brain. Proc. Natl. Acad. Sci. U.S.A. 71, 1725 - 1729 (1974)

24 Muzio, F., Malandrino, S., Ferrari, M. and Tonon, G.: Temperature effect on subclasses of muscarinic receptors in rat colon, heart and cerebral cortex. Life Sci. 39, 365-371 (1986)

25 Valention, R, and Dingledine, R.: Presynaptic inhibitory effect of acetylcholine in the hippocampus. J. Neurosci. 1, 784-792 (1981)

26 Briggs, R.S., Redgrave, P. and Nahorski, S.R.: Effect of kainic acid lesions on muscarinic agonist receptor subtypes in rat striatum. Brain Res. 206, $451-456$ (1981)

27 Yoshizaki, T.: Participation of muscarinic receptor on splanchnic-adrenal transmission in the rat. Japan. J. Pharmacol. 23, 813-816 (1973)

28 Role, L.W. and Perlman, R.L.: Both nicotinic and muscarinic receptors mediate catecholamine secretion by isolated guinea-pig chromaffin cells. Neuroscience 10, 979 - 985 (1983)

29 Douglas, W.W., Kanno, T. and Sampson, R.S.: Effects of acetylcholine and other medullary secretagogues and antagonists on the membrane potential of adrenal chromaffin cells: An analysis employing techniques of tissue culture. J. Physiol. (Lond.) 188, 107 - 120 (1967) 
30 Akaike, A., Mine, Y., Sasa, M. and Takaori, S.: Voltage and current clamp studies of muscarinic and nicotinic excitation of the rat adrenal chromaffin cells. J. Pharmacol. Exp. Ther. 255, 333-339 (1990)

31 Akaike, A., Mine, Y., Sasa, M. and Takaori, S.: A patch clamp study of muscarinic excitation of the rat adrenal chromaffin cells. J. Pharmacol. Exp. Ther. 255, 340-345 (1990)

32 Hamill, O.P., Marty, A., Neher, E., Sakmann, B. and Sigworth, F.J.: Improved patch-clamp techniques for high-resolution current recording from cells and cell-free membrane patchers. Pflugers Arch. 391, $85-100$ (1981)

33 Sachs, F., Neil, J. and Barkakati, N.: The automated analysis of data from single ionic channels. Pflugers Arch. 395, 331 - 340 (1982)

34 Akaike, A., Ikeda, S.R., Brookes, N., Pascuzzo, G.J., Rickett, D.L. and Albuquerque, E.X.: The nature of interaction of pyridostigmine with the nicotinic receptor-ionic channel complex II. Patch clamp studies. Mol. Pharmacol. 25, 102-112 (1984)

35 Brandt, B.L., Hagiwara, W., Kidokoro, Y. and Miyazaki, S.: Action potentials in the rat chromaffin cell and effects of acetylcholine. J. Physiol. (Lond.) 263, $417-439$ (1976)

36 Marty, A. and Neher, E.: Potassium channels in cultured bovine adrenal chromaffin cells. J. Physiol. (Lond.) 367, 117-141 (1985)

37 Lattore, R. and Miller, C.: Conductance and selectivity in potassium channels. J. Membr. Biol. 71, $11-30(1983)$

38 Morita, K., North, R.A. and Tokimasa, T.: Muscarinic agonists inactivate potassium conductance of guinea-pig myenteric neurons. J. Physiol. (Lond.) 333, 125 - 139 (1982)

39 Cassell, J.F. and McLachlan, E.M.: Muscarinic agonists block five different potassium conductance in guinea-pig sympathetic neurones. Br. J. Pharmacol. 91, 259-261 (1987)

40 Sakmann, B., Noda, A. and Trautwein, W.: Acetylcholine activation of single muscarinic $\mathbf{K}^{1}$ channcls in isolated pacemaker cells of the mammalian heart. Nature 303, 250-253 (1983)

41 Kurachi, Y., Nakashima, T. and Sugimoto, T.: On the mechanisms of activation of muscarinic $\mathrm{K}^{+}$channels by adenosine in isolated atrial cells: Involvement of GTP-binding proteins. Pflugers Arch. 407, 264-274 (1986)

42 Kurachi, Y.: Voltage-dependent activation of the inward-rectificr potassium channel in the ventricular cell membrane of guinea-pig heart. J. Physiol. (Lond.) 366, 365-385 (1985)

43 Breitwieser, G.E. and Szabo, G.: Mechanisms of muscarinic receptor-induced $\mathrm{K}^{+}$channel activation as revealed by hydrolysis-resistant GTP analogues. J. Gen. Physiol. 91, 469-493 (1988)

44 Pfaffinger, P.J., Martin, N.M., Hunter, D.D., Nathanson, N.M. and Hille, B.: GTP-binding proteins couple cardiac muscarinic receptors to a $\mathrm{K}^{+}$ channel. Nature 317, 536-538 (1985) 